\title{
SDG's, the State, and Data Accuracy of Sexual Violence in Indonesia
}

\author{
Khaerul Umam Noer ${ }^{1}$, Siti Chadijah ${ }^{2}$, Endang Rudiatin ${ }^{3}$ \\ \{umam.noer@umj.ac.id ${ }^{1}$ \} \\ Department of Public Administration, University of Muhammadiyah Jakarta, 15419, Jakarta, Indonesia ${ }^{1}$ \\ School of Graduate Program, University of Muhammadiyah Jakarta, 15419, Jakarta, Indonesia ${ }^{2}$ \\ Department of Social Welfare, University of Muhammadiyah Jakarta, 15419, Jakarta, Indonesia ${ }^{3}$
}

\begin{abstract}
The number of violence against women in Indonesia continues to increase every year, whereas the elimination of violence against women is one of the SDG indicators. The data released by the National Commission on Violence Against Women and the Ministry of Women's Empowerment and Child Protection confirmed this situation. The problem is, although the two state institutions regularly release data on violence against women, the data released does not nationally represent the data on violence. This study aims to find reasons on why data on violence in Indonesia cannot be used as material for policy making. By using ethnographic methods, this study found a number of facts why the data on violence in Indonesia is so unreliable. At the ministry level, the main constraints are with the forms that are difficult to fill in, the model of tiered bureaucracy that is useful for reporting, but with the higher the level, the less violence data there are, the limited number of registrar. Whereas National Commission on Violence Against Women data are constrained by a centralized and voluntary data collection model, that more than $65 \%$ of partners do not return the data collection forms. This results in both the Ministry and the Komnas Perempuan data being just the tip of the iceberg of the problem of violence against women in Indonesia.
\end{abstract}

Keywords: Violence against women, Women rights, Human rights, Violence data, Komnas Perempuan

\section{Introduction}

This research is based on one fundamental statement: Indonesia's state of emergency on violence against women. The National Commission on Violence against Women (hereinafter stated as Komnas Perempuan) End Year Notes [1] during 2019 recorded 431,471 cases of violence, an increase of $6 \%$ from 2018 of 406,178 cases [2]. From these data, 87\% of those cases of violence are sexual violence against women. The Ministry of Women's Empowerment and Child Protection (hereinafter abbreviated as MoWECP) recorded that in 2019, there were 1,567 cases of violence against women [3]. It is surprising, that the two state institutions produce very much different data. Even if we use the Komnas Perempuan's data, when compared to the total population of Indonesia which is more than 267 million, the number of reported violence is only $0.2 \%$ of the population.

If we look at the data on violence against women that occurred in more than a decade, we can see that the trend of violence experienced by women has increased from year to year. Komnas Perempuan noted that in 2018 there were 406,178 reported cases of violence against 
women, and this figure had increased sharply from 348,446 cases in 2017, and 259,150 cases in 2016 [4][5]. However, although statistics on cases of violence are available, they do not indicate the true magnitude of the problem. The lack of credible data in Indonesia and the many cases of violence against women throughout Indonesia that are not reported have become a major obstacle in taking effective action in eliminating violence against women [6]-[8].

There has been much criticism about the unreliable data on violence in Indonesia [9] especially the validity and reliability of data on violence against women produced by institutions such as the Komnas Perempuan and the MoWECP [10]. Data on violence against women collected by the Komnas Perempuan does not guarantee the accuracy of the data because the largest source of data collected is from the religious court instead of from the police data. Even though the data collection of cases of domestic violence shows data that continues to increase throughout the year, the data does not collect basic information on how many women victims of domestic violence were killed by their husbands or partners. In this case, the government is still collecting data that is general and not detailed. On the other hand, the validity of data in the Religious Courts referred to by Komnas Perempuan is also questionable, because $85 \%$ of those is data of divorce with violence even though in practice there are differences in perception that not all divorces are caused by violence. This can be seen from the classification of court decision data by the Supreme Court which confused the cause of divorce [11].

In Indonesia, there are currently two institutions that play the role of coordinators of data collection on violence against women that become national data references: the MoWECP with the Online Information System for the Protection of Women and Children (MoWECP Symphony) and the National Commission on Violence against Women (Komnas Perempuan) with a data collection system through its annual End of Year Notes (Catatan Akhir Tahun/Catahu). The problem is, both the data made by the Komnas Perempuan and the MoWECP are invalid, even absurd. For example, the Komnas Perempuan recorded that the Provinces of Maluku, North Maluku, Papua and West Papua had zero violence. The same thing also comes from MoWECP data. This is certainly not realistic where in these regions, especially Papua and West Papua, HIV/AIDS prevalence and sexual violence are very high. Not to mention the many rules of customary laws that harm women's rights or discriminate against women. In comparison, a comprehensive study of violence in Papua found that $60 \%$ of men who had partnered claimed to have committed physical and/or sexual violence against their intimate partners and nearly 44 percent of men who had ever partnered stated have raped their partners [12].

This study aims to explain difficulties in data collection on violence in Indonesia. With a focus on how the violence data collection model is carried out by Komnas Perempuan and the MoWECP, and what are the strengths and weaknesses of each model. Violence data still needs to be addressed by various parties, considering that the statistics of the figure need to be read as an iceberg phenomenon that does not describe the true state of violence against women in society [13].

\section{Method}

This research uses ethnographic methods, by conducting in-depth interviews with the Komnas Perempuan research division, the data collection division of the MoWECP, and directly visiting the Integrated Women's Empowerment and Child Protection Service Centers in five cities: Depok City, Bekasi City, Bekasi Regency, Bogor City, and Bogor Regency. In addition 
to conducting interviews, the research team also conducted direct observations to see how the data collection was carried out, technical and detailed implementation of data collection, and how the data was tabulated. In addition, the team also reviewed various policy documents on data collection on violence against women in Indonesia, starting from the regional level to the central government.

\section{Results and Discussion}

\subsection{The MoWECP's data versus Komnas Perempuan's data}

The Ministry of Women's Empowerment and Child Protection (Kementerian Pemberdayaan Perempuan Perempuan dan Perlindungan Anak/KPPPA) was established in 1978, previously named the Deputy Minister for Women's Role. Initially the MoWECP focused more on the economic empowerment of women in the household, but since 2009, under Linda Amelia Sari, the ministry expanded its scope of work, not only to economic and social issues for women, but also protection for children.

The MoWECP has its task of organizing the affairs of women's empowerment and child protection in the government to assist the President in organizing state government. In formulating and determining policies, coordinating and synchronizing policy implementation, and supervision related to women's empowerment and child protection, this task includes protection of women and children from violence against them. The violence data collection model conducted through the Online Information System for the Protection of Women and Children (MoWECP Symphony). The MoWECP' Symphony is carried out in stages, starting from partner data in each city, to Integrated Women's Empowerment and Child Protection Service Centers (Pusat Pelayanan Terpadu Pemberdayaan Perempuan dan Perlindungan Anak/P2TP2A) data in each city, up to the provincial level P2TP2A, and ends at the national data level. The national data is then processed into MoWECP Symphony data

Considering the complexity of the bureaucratic pathway, thus since 2002, the government established the P2TP2A, and has been formed in 34 provinces and 390 regencies/cities in Indonesia [14]. The existence of P2TP2A as an embodiment of an integrated service mechanism between the Government and the community with the composition of its membership consists of various elements such as the Police, Attorney's Office, Court of Law, Regional Office of Law and Human Rights, Regional Office/Office of Religion, Regional Development Planning Agency (Badan Perencanaan dan Pembangunan Daerah/Bappeda), Office of Health, Office of Social Affairs, Office of Labor, Office of Education, as well as community organizations, religious institutions, professional institutions, and academics.

In addition to providing case handling services, P2TP2A also provides data collection and documentation of cases handled by each agency/institution. This is where the MoWECP obtains some of the violence data published annually. In 2010, the MoWECP issued the Guidelines on the System for Data Recording and Reporting on Violence against Women and Children which must be used by all levels of government, from the central government to the regional governments. This also includes all organizations that are partners and are members of P2TP2A. It is at this point that the issue becomes crucial to underline, that even though there is a format that must be filled in, factually, data collection and documentation have not gone well.

There are two reasons why this system is not working well. First, the recording model carried out by P2TP2A is very bureaucratic and time consuming. With a tiered reporting model, 
violence data collection should be easier to do. But the facts in the field, the higher the level of reporting, and the fewer cases are recorded. There are many incidents where cases of violence are very high in one city, but when they go up to the provincial level, the case data number is reduced. This causes the emergence of the pyramid model, where the higher the level of government, the less violence data recorded.

To understand why this is happening, it is important to look at what is happening at the lowest level: P2TP2A at the city level. Periodically, once a year, city level P2TP2A must report the data to provincial level P2TP2A. There are 28 forms pages, with more than 76 columns that must be filled for each reporting period. Each report must include complete report details for each case, each case requiring no less than 12 sheets of form, with 53 columns to be filled in, not including image documentation, post mortem evidence, Minutes of Police Examination, trial transcripts, verdicts and other reports. Another reason why P2TP2A does not have an adequate recording system is due to the absence of individuals who have special competence in recording using the database and documentation system. This reason arises more because of the complicated data collection model carried out by P2TP2A. This is due to the P2TP2A's data collection system is sourced from data collected from service providers and other working partners, which in many cases are extremely incomplete.

In addition to the MoWECP Symphony, data on violence against women was also issued by Komnas Perempuan. Komnas Perempuan has a mandate to carry out monitoring, including fact finding and documenting of violence against women and violations of women's human rights, as well as dissemination of the results of monitoring to the public and taking steps that encourage accountability and handling of victims of violence. Furthermore, Komnas Perempuan also provides advice and considerations to the government, legislative and judicial bodies, and community organizations to encourage the preparation and legalization of a legal framework and policies that support efforts to prevent and overcome all forms of violence against women, as well as protection, enforcement and promotion of women's human rights.

From the beginning, Komnas Perempuan has always provided an annual report on the data collection of cases of violence against women through the Komnas Perempuan End of Year Record annually. The data was compiled by Komnas Perempuan from three sources: (1) District Court and Religious Court, (2) Komnas Perempuan partner service institutions, and (3) the internals of Komnas Perempuan itself, which in this case coming from two units: Service and Referral Unit (Unit Pelayanan dan Rujukan/UPR) formed to receive reports from victims who came directly to the Komnas Perempuan, and the Monitoring Unit that manages reports that come in via mail and electronic mail.

There are at least three problems in the data collection conducted by Komnas Perempuan. First, the violence data from the District Court and the Religious Court cannot be fully used because it is very general. Court data only covers divorce and domestic violence data that has been tried and has legal force. No details of violence arose from trial cases, for example violence such as what happened, who were the victims and perpetrators, or in what context the violence occurred. Details like this are usually in the police, whose data are not actually used by Komnas Perempuan. In addition, because trial data are cases that end in court, there is no data regarding the handling of cases of violence that do not reach the court, either through mediation or victims who withdraw their reports. As a result, the violence data from the court is only the tip of the iceberg of various cases of violence.

Second, although Komnas Perempuan's data collection model is advantageous because it cuts off the bureaucratic pathway which makes the potential for data on violence lessens, or even lost, this data collection model is very dependent on the willingness of partner service institutions to submit data. Unlike the MoWECP Symphony data collection model, which is 
carried out in stages, the Komnas Perempuan data collection model is carried out directly in each region. Komnas Perempuan directly requests data from all service partners in all regions, including P2TP2A and various NGOs and CSOs engaged in protecting victims of violence. The problem is, this data collection is voluntary, meaning that each institution will be given a number of data collection forms but there is no obligation or any mechanism from Komnas Perempuan to collect the forms that have been given.

Third, internally Komnas Perempuan also opened report and service posts for victims of violence, but the level of reporting was very low. This problem lies with the Komnas Perempuan's institution is centered in Jakarta. Komnas Perempuan does not have a regional representative office, so everyone who wishes to report to Komnas Perempuan must visit the Komnas Perempuan's office in Jakarta. Thus, this system is directly limiting access for women in remote areas to obtain direct services provided by Komnas Perempuan. The only way for women in remote areas to report to Komnas Perempuan is only through partner institutions, whose reports of their handling will be given to Komnas Perempuan.

\subsection{Why Data Matters?}

Data collection is very important, because it is a source of information about existing acts of violence, as well as how the handling of cases is carried out and what the follow-up. Poor handling of cases can result in the bad data collection cases as well, likewise, bad data collection will result in poor handling policies as well. The issue of data collection will be related to how and by whom the data is inputted. The unclear standard mechanism of cases handling in service institutions or agencies makes it difficult to do data collection especially when it is added by the lack of human resources inputting the data. Even if each institution has officers who specifically tasked to register, the officer does not necessarily have an understanding of the importance of a complete and accurate data collection [15][16]. With such a tendency, it cannot be denied that there is an increasing number of cases of violence against women that are not reported or underreported data by the public or reported but the development of cases are unclear or stalled in law enforcement officers because the data collection of cases that have not been optimal.

In this case, data collection on violence against women can be done in two ways: through surveys and administrative record data collection models. The main advantage of recording violence through surveys is that prevalence rates can be calculated, so that patterns or generalizations of violence cases can be generated. The survey results can provide detailed information related to victims of violence or perpetrators such as socio-demographic characteristics, attitudes/behaviors, and experiences of past acts of violence. The biggest problem of this model is the distribution of Indonesia's territory that is very vast and population density that is uneven. If it is only focused on the city, the survey model cannot capture the problem of women in rural areas, and vice versa. Too wide demographic coverage makes the survey model difficult, not to say impossible, to do.

With the limitations of the survey model, the state, through MoWECP Symphony and Komnas Perempuan, chose to use the administrative data collection model. The administrative data collection on violence against women offers several advantages. First, these administrative records are usually collected regularly which may involve a number of institutions/organizations. Because every report of a violent incident is recorded, the data obtained can be more up-to-date. Second, in terms of funding, administrative records are certainly cheaper and more cost-effective compared to surveys that must be conducted every year with rather large funds [17]. The data collection model undertaken by the MoWECP 
Symphony and Komnas Perempuan is an administrative data collection model, because it is based on direct reports in each region.

However, there are some fundamental weaknesses in the administrative data collection model, namely: (1) data from administrative records cannot be used to calculate prevalence rate because administrative records are designed and intended for recording purposes only, therefore the information is limited and only provides information on the number of recorded cases. In addition, the use of administrative records is also often constrained by data coverage so that its use is very limited. (2) The definition used does not follow international standards so that it may produce figures that cannot be compared with other countries. (3) inconsistencies in the application of data collection and quality assurance as well as missing data due to mistakes of officers or officers with indifferent attitude.

\section{Conclusion}

In early 2020, the Komnas Perempuan published an Annual End Year Notes, which for the umpteenth time, the data was very different from the MoWECP Symphony data. Both systems, the MoWECP Symphony and the Komnas Perempuan year End Notes each has a number of advantages and disadvantages. The main strength of MoWECP Symphony data lies in the guideline of recording and reporting system on data of violence against women and children in 2010, which is mandatory, in accordance to the guidelines on data collecting and reporting, carried out in stages and coordinated, and because it is mandatory, there will be a warning because it has become a part of institutional performance standard. The main disadvantage of the MoWECP model is that there is no verification mechanism that ensures whether the data collected and reported is in accordance with the existing guidelines, and ensures the validity of the data at the local level all the way to the national level. This is due to the lack of monitoring and evaluation of data collection conducted by the region, whether or not it is in line with the MoWECP guidelines. In addition, the recording of violence against women of MoWECP is still mixed between men and women, not to mention the data on child violence which is also unclear in the details of the report. The system developed by Komnas Perempuan has its advantages in the data collection system that is in collaboration with partner institutions, both central and regional. This system is more reliable due to the real time case handling data from partners and P2TP2A. However, the main weakness of this system lays in the voluntary reporting basis and that there are no sanctions, which results in a forms' very low rate of return, whereby in practice only $10-30 \%$ of partner institutions return the forms to Komnas Perempuan each year. In addition, there is no organizational structure that reaches all the way to the regions, and there is no monitoring and coordination for institutions that do not return the data collection forms so that the data collection processes have not been coordinated and tiered. These two models, the MoWECP and Komnas Perempuan, basically can be integrated through the One Data Indonesia model. But the main challenge lies precisely in the sectoral ego that is still strong in each institution. This becomes an obstacle in making an integrated violence data collection, which in turn will make it difficult to make policies to handle and eradicate cases of violence in Indonesia. 


\section{Acknowledgement}

This research is fully supported by the assistance of the Ministry of Research and Technology/The National Research and Innovation Agency (Ristek/BRIN). We would like to thank the Ministry of Research and Technology/The National Research and Innovation Agency, LLDIKTI 3, the Rector of University of Muhammadiyah Jakarta, the Research and Community Service Agency of University of Muhammadiyah Jakarta, and the Dean of the Faculty of Social and Political Sciences for all their assistance and facilitation.

\section{References}

[1] K. Perempuan, "Komnas Perempuan's End Year Notes 2019," Jakarta, 2020.

[2] K. Perempuan, “Komnas Perempuan's End Year Notes 2018," Jakarta, 2019.

[3] M. of W. E. and C. Protection, "Gender Equality Outlook 2019," Jakarta, 2020.

[4] K. Perempuan, "Komnas Perempuan's End Year Notes 2017," Jakarta, 2018.

[5] K. Perempuan, "Komnas Perempuan's End Year Notes 2016," Jakarta, 2017.

[6] S. Irianto and A. Cahyadi, The Collapse of Civil and Criminal Barriers: A Case Study of Violence Against Women. Jakarta: Yayasan Obor, 2008.

[7] UNFPA Indonesia, "The Role of Data Adressing Violence Against Women and Girls," Jakarta, 2013.

[8] M. of W. E. and C. Protection, "Gender Equality Outlook 2017,” Jakarta, 2018.

[9] F. A. Syukur, Mediation of Domestic Violence Case Theory and Practice in the Indonesian Court, Mandar Maj. Bandung, 2011.

[10] T. Parikesit and R. Maryam, Urgency Applying Domestic Violence Screening on Divorce Mediation Cases in Religious Court, Universita. Yogyakarta, 2018.

[11] F. A. Kodir and U. Azizah, Reference for Religious Court Judges regarding Domestic Violence, Komnas Per. Jakarta, 2013.

[12] UNWOMEN, "United nations Secretary - General's Coordinated Database on Violence Againts Women, Questionnaire to Member State," New York, 2017.

[13] K. U. Noer and N. L. G. Madewanti, "Too many Stages, Too Little Time : Bureaucratization and Impasse in the Social Safety Net Program in Indonesia,” J. Stud. Pemerintahan, vol. 11, no. 3, pp. 370-400, 2020.

[14] K. Perempuan and F. P. Layanan, "Empowerment of Empowering Services: P2TP2A Assessment Results in 16 Provinces," Jakarta, 2017.

[15] MAMPU, "Literature Review Violence Against Women in Indonesia. Policy Oriented Research on Government Services and Law on Violence Against Women in Indonesia," Jakarta, 2015.

[16] K. U. Noer, "Land, Marriage and Social Exclusion: The Case of Madurese Exile Widow," Procedia - Soc. Behav. Sci., vol. 65, no. ICIBSoS, pp. 180-185, 2012, doi: 10.1016/j.sbspro.2012.11.108.

[17] M. of W. E. and C. Protection and Central Bureau of Statistics, "Thematic Gender Statistics: End Violence against Women and Children in Indonesia," Jakarta, 2017. 